\title{
Displacement and Family Separation of Australian Aborigines as Depicted in Memoirs of Stolen Generation
}

\begin{abstract}
The treatment of indigenous tribes during the colonization of Australia has always been a subject widely discussed and analysed. Nevertheless, the way in which Australian Aboriginal people were forced to migrate within Australia and how the government executed the brutal plan of separating indigenous children from their families and homeland is a unique phenomenon. The trauma of displacement still exerts a dramatic impact on generations of indigenous people as their well-being results from their interaction with the land of their ancestors. The aim of this article is to familiarise the reader with the history of Aboriginal trauma through the analysis of their testimonials and memoirs collected by a governmental committee for the sake of publishing the Report of the National Inquiry into the Separation of Aboriginal and Torres Strait Islander Children from Their Families. It is hardly possible to employ any contemporary theory of trauma in this analysis, but the author's findings have undeniably factual value.
\end{abstract}

Keywords: Aborigines, Stolen Generation, trans-generational trauma, displacement, forced internal migration.

While discussing the severe, far-reaching impact of family separation on Aboriginal people - a result of forced internal migration - one needs to remember that Aboriginal culture has always been entirely oral. Even today, written medium is still mainly avoided ${ }^{1}$ by the Traditional Custodians

1 That is admitted e.g. by contemporary Aboriginal right activist and poet, Lionel Fogarty, in his poem Tired of Writing: "...to write I have to use a medium that is not mine". 
of the South Land of Holy Spirit². Up to the 1970s, the Australian government banned Aboriginal people from speaking their tribal languages and because of the family separation policy, a majority of indigenous languages- having no written records of the past- have been permanently lost. There are very few dictionaries of Aboriginal tribal languages - such as Yidinj, for instance, - which are being revitalised by combined efforts of linguists and indigenous people. Kuku-Yalanji indigenous speakers are currently struggling to revive their language. One of the words from their mother tongue that they have started using in their Aboriginal-English is $B u b u$ - meaning "land of our ancestors". They believe the word derives from Buba - meaning "a baby, small child" because both of them need the same care and would die if left alone ${ }^{3}$. The comparison between a land, a little baby and diminutives used in both cases show the relation of Aboriginal people to their homeland. The linguistic correlation helps illustrate the tremendous impact that the forced internal migration exhorted on the lives of indigenous tribes. In this case, one is not facing the nostalgia that the western world can understand talking about leaving their homeland. The relation of Aboriginal people to their Bubu is based on a strong spiritual and emotional bond and communication with the ancestors' spirits. When simultaneously deprived of their children and land, they were exposed to such a stress level that resulted in an extremely high rate of mental disease, suicide and other medical issues placing Traditional Custodians on the verge of extinction.

The Report of the National Inquiry into the Separation of Aboriginal and Torres Strait Islander Children from Their Families (1997) ${ }^{4}$, which is treated by the Australian Government as an attempt to account for the infamous policy of 1900-1970 aiming at whitening Australia, is a publication of particular importance, but also of unique rudiments. It is a document that allows white citizens of Australia and the whole world to understand the cruelty of procedures under which the aboriginal children were forced to assimilate; taken from their parents to faraway lands by force or deceit, brought up in institutions run by the state or after unlawful adoption i.e. raised by white families. The Report is not a scientific or academic publication, and the fact that it can be classified as a literary reportage, one of the

2 Australia was called so by Captain Pedro Fernandez de Quiros, on the Day of Pentecost, 14 May 1606.

3 The author learnt the fact staying with Kuku-Yalanji people in Mossman Gorge.

4 The Report of the National Inquiry into the Separation of Aboriginal and Torres Strait Islander Children from Their Families, published by Commonwealth of Australia in 1997, further on will be referred to in this article as The Report. 
literary genres the most difficult to define, has raised much controversy over the historiographic value of the groundbreaking work.

The controversy and negative reception by the nation was not altered by the fact that the government appointed lawyers responsible for an appropriate legal form of the Report, acceptable for both parties i.e. the government and tribal elders, and providing the document with a number of clauses protecting real authors. The Commission was given 1.5 year to gather evidence: altogether, "they listened to 535 personal stories of forcible removal and had access to another thousand or so in a written form" 5 . Their work began on August 2, 1995, upon the decision of Michael Lavarch, the Attorney General of the Australian Commonwealth. However, the final version of the Report was released in 1997 due to the work and commitment of hundreds of people and the generous hearts of the Aborigines who decided to approach the Report's postulators with trust. That work is an attempt to confront the Australian nation, and above all the ruling government, with the trauma of the stolen generation. Through the words of Aborigines, who agreed to tell their stories, the report reveals generally accepted and broadly applied practices employed to "whiten Australia" and annihilate indigenous people who currently constitute less than $2 \%$ of the continent's population.

The Report is largely the first historical collection of stories recalled by Aborigines which were recorded for future generations using a medium new to the Aboriginal culture. The stories, that had been transmitted orally so far, were written down as originally spoken, by qualified reporters or by the authors of those memoirs themselves. Most people had their names changed, but a few decided to retain their real identity, explaining that only then the revealed truth that had been suppressed for so many years will exhort a fully cathartic influence on themselves and their family members. These are memoirs written at the end of the last century that clearly explain the genesis of the psycho-sociological phenomenon of "intergenerational trauma". Their analysis provides irrefutable evidence that the poor quality of life of the Aboriginal communities in present time is a direct result of the practices applied by the government in the past. Having been deprived of family ties, the influence of ancestors, knowledge of language and culture, the Aboriginal people today drift like a ship with lowered sails crashing on the rocks of the system imposed by the white colonizers.

"White Australia" did not respond positively to the Report or to the apology addressed to the Aboriginal people. The year 2008 did not bring

5 The Stolen Children - Their stories, ed. C. Bird, Random House Australia Pty Ltd, Sydney 1998, p. XIV. 
a breakthrough, despite the enormous joy of the Aborigines after hearing the words of the national confession. White Australians saw no reason to apologize for anything, because - as they kept explaining - their generation did nothing wrong. As a consequence of the governmental apology, Prime Minister Rudd lost the nation's support. The Report had already divided the public opinion because the descendants of the colonisers absolutely did not understand the spirit in which the document had been created and approached it in a manner similar to a judge in a courtroom - they demanded evidence and accused the commission of lack of objectivity and credibility. The situation did not improve over time, on the contrary - there was a huge public outcry against the conclusions of the Report. Politicians as respected as Prime Minister John Howard got involved into heated polemics over the final conclusion of the report. He negated the statement that what had happened to the Aboriginal race was genocide. Despite being a politician who perfectly knows legal acts signed by Australia, Howard ignored the main presuppositions of the UN Convention on the Prevention and Punishment of the Crime of Genocide (1948) that Australia had signed in 1951. The Convention clearly defines one of the forms of genocide as "the transfer of offsprings of one ethnic group to another using force".

One of the basic reasons for the negative reception of the Report by the public is the fact that its form caused some inaccuracies. It was supposed to be a reportage, and yet the emotional presentation of the facts blemished the reception of the whole. Followers of the theory that reportage is not literature but sheer facts were dealing this time with such a reportage which should be definitely classified as literature. Literary academics when faced with such problematic borderline literature claim that "reportage is [...] a journalistic genre reaching for the artistic means of literary prose. Contrary to literary fiction it is based on authentic material, but this authentic material in a reportage is often modeled on the epic plot, organized into some expressive action"6.

The reaction of the white Australian community to the Report showed surprisingly low level of awareness of the crimes and the wickedness of the colonizers towards the indigenous. Reading Aboriginal memoirs, it is difficult to remain emotionally unmoved, and yet most Australians found these stories unreliable. This reaction can be explained by Olick's consideration of collective memory. He emphasizes, using the word game between English member and remember that:

6 M. Głowiński, A. Okopień-Sławińska, J. Sławiński, Zarys teorii literatury, Warszawa 1991, p. 390 (all translations into English are done by the author of the article). 
It's not just that we remember as members of groups, but also at the same time we form these groups and create [ourselves as] their members by the act of remembering [re-member-ing]. Thus, remembering is a special kind of social activity and at the same time shows how the group determines the activity of the individual that belongs to it, and that the activity of the individual as a member of the community is a condition of the existence of the group ${ }^{7}$.

The uniqueness of this groundbreaking work which was supposed to lead to transformation and reconciliation in Aboriginal relations with white Australians, was also based on the assumption that the stories the Aborigines would like to share will not be questioned or verified in any way. The Aborigine's words regarding the Stolen Generation were to be treated as historical fact. This turned out to be unacceptable to the white community, but the Government's Report Commission upheld the assumptions with a firm voice:

The nature of the Inquiry process and of the information sought and provided meant that evidence and submissions could not be tested as thoroughly as would occur in a courtroom. This applies to all the evidence. Indeed, as this report indicates, much supporting evidence, including records, has been destroyed. The submissions from the individuals, organisations and governments are important. We carefully report what we have heard so that the community generally will know the different perspectives on what has occurred. We also sought out independent sources where possible and include them in this report. We have ensured that our findings, conclusions and recommendations are supported by the overwhelming weight of evidence ${ }^{8}$.

Veronica Tozzi holds the same position in her innovative article, "Privileges of Testimony, History, Memory and Literature in Disputes About the Construction of the Recent Past", where she confirms the special role of extermination testimonies in literature. Tozzi argues that, "literature and art are treated as a privileged form of testimony given by the victims of terror, because they exhibit greater sensitivity than academic history, fighting loudly so that the horror could not be forgotten:"9

It's all about appreciating, but not in the foundationist spirit, the cognitive and moral role of testimony in establishing a representation of the near past. [...] Here I am trying to take a line of argument far from epistemological and at the same time moral position, based on the conviction of the privileged perspective of the victims, an argument turning towards the analysis of the process of creating and circulating of the testimonies as a factor contributing to the constitution of the past. Such

7 M. Kobielska, Pamięć zbiorowa w centrum nowoczesności. Ujęcie Jeffreya K. Olicka, IBL PAN, "Teksty Drugie" 2010, No 6, p. 182.

8 The Stolen Children - Their stories, ed. C. Bird, Sydney 1998, p. V.

9 V. Tozzi, Przywileje świadectwa. Historia, pamięć i literatura w sporach o konstruowanie nieodległej przeszłości, transl. E. \& J. Zięba, A. Calderón Puerta, “Teksty Drugie” 2010, No 6, pp. 11-12. 
a strategy, adopting a new epistemology of testimony, involves treating a testimony not so much as a journey into the past, but as an activity in the present tense, which aims to make others realize, first of all, that believing in a testimony is the basic condition for accepting knowledge - testimonies are not secondary sources of knowledge or parasitism on experience and understanding, and secondly that the creation and circulation of memoirs plays an important role not only in the assessment of materials, but also legally constitutes knowledge ${ }^{10}$.

In this way Tozzi, although her literary research into the presentation of trauma in literature is probably not known to the supporters of the $R e$ port, managed to define - according to academic register - the ground rules that the Report's postulators wanted society to comply with.

Taking the reflection on the representation of Stolen Generation's trauma in the literature one step further, it is worth quoting Marianne Hirsch's approach to mechanisms of generating post-memory. She emphasizes the importance of "separating the memory of those who experienced specific events [...] and those born later, free from this type of experience"11. In other words, "post-memory becomes a space of a particular generational community, the space of constant redefining of meanings, but also the space of oppression by some institutions imposing strategies of remembering on the communities" 12 .

Some of the testimonies that will be analysed in this article are the part of an extraordinary book titled Stolen Children - Their Stories. Through the emotional confessions made by the victims of forced displacement and family separation the book illustrates gruesome facts of the history of Aboriginal children who were taken to other parts of Australia by compulsion, duress or undue influence (that is exactly why the generation is referred to as stolen, as this is literally what happened to them). Ronald Wilson states in the preface that the process of sharing life's traumatic stories is the beginning of a healing process that can continue only if followed by an "acknowledgement of the shameful deeds of the past and genuine expression of regret. Reparation can then be followed through with practical measures designed to facilitate reunions, to ensure access to culturally appropriate counseling and compensation"13. He also tries to answer misgivings of those accusing the Report as lacking in credibility. "These critics must have expected the Commission to embark on the process of investigation so as to discover the evidence of wrongdoing that would stand up in

\footnotetext{
10 Ibidem. pp. 12-13.

11 M. Wójcik-Dudek, W(y)czytać zagładę, Wydawnictwo Uniwersytetu Śląskiego, Katowice 2016, p. 8.

12 Ibidem.

13 Stolen Children ..., op. cit., p. XIV -XV.
} 
court"14. He explains this is not that kind of report, but one "that must be read with an open heart and mind, and with willingness to listen, and to listen intently"15.

Hayden White also sheds some light on the Report's critics' dilemma:

The form of the discourse, the narrative, adds nothing to the content of the representation, but is rather a simulacrum of the structure and processes of real events. And insofar as this representation resembles the events of which it is a representation, it can be taken as a true account. The story told in the narrative is a "mimesis" of the story lived in some region of historical reality, and in so far as it is an accurate imitation it is to be considered a truthful account thereof 16 .

Bearing in mind that the main objective of the Report is to start the healing process, one should remember that, as Cathy Caruth argues: "Trauma itself may provide the very link between cultures; not as a simple understanding of the pasts of others but rather, within the traumas of contemporary history, as our ability to listen through the departures we have all taken from ourselves"17. Additionally, Caruth postulates in her study that: "If trauma is a bridge between different historical experiences, listening to another person's traumatic story can create strong intercultural bonds and new forms of community"18.

The stories that will be analysed at this point will help the reader to grasp the immensity of suffering that was brought upon the displaced and separated families. Aboriginal children that had so far been taught by their relatives how important the ancestors' land is, were doomed to life without roots, language and cultural understanding. One of the most moving texts that one can find in the Report is a testimony of Donna Meehan, one of very few victims who decided to write under their real name. It is a story full of photographic details, which clearly shows what kind of trauma a little girl experienced having been separated from her mother and taken to a foreign land. After so many years she still can recollect the colours and sounds, intensity of light and shadows remembered at the moment of parting on the railroad platform. The sophisticated language and its complexity gives

14 Ibidem, p. XIII.

15 Ibidem.

16 H. White, The Question of Narrative in Contemporary Historical Theory, "History and Theory", Wesleyan University Press, Vol. 23, No. 1 (Feb., 1984), pp. 1-33, p. 3, https://www.jstor.org/ stable/2504969 [accessed: 12.04.2019], DOI: http://dx.doi.org/10.2307/2504969.

17 C. Caruth, Trauma and Experience, [in:] Trauma: Explorations in Memory, ed. C. Caruth, The John Hopkins University Press, Baltimore and London 1995, p. 11.

18 S. Craps, Beyond Eurocentrism: Trauma Theory in the Global Age, [in:] The Future of Trauma Theory: Contemporary Literary and Cultural Criticism, ed. G. Buelens, S. Durrant, R. Eaglestone, Abingdon, Routledge 2014, pp. 418-419. 
the testimony a special place among other stories gathered in the Report. To some extent that may blur reception, but it also clearly indicates that one should not forget about cases when Aboriginal children spent their lives with caring white families and were treated with love and respect and got decent educations (that is by no means an attempt to justify the soulless family separation procedure).

Donna, raised in a pastor's family, had everything a girl could dream of - from feelings to expensive toys, which, however, did not change the fact that she did not manage to gain inner peace. She called her teddy bears Widdy and Barry ( her brothers names), confided only to them and hugged them "because in this way the older brothers who disappeared somewhere on the platform were always with her". Donna begins her tale of family separation, as follows:

Mum had all us kids dressed up, our hair brushed which was only done for special days, and we were constantly reminded to use our manners. Barry, Widdy, Robby, Sooty and myself were put in the back seat of a taxi while mum sat in the front seat with the driver. The lady taxi-driver had known all the kids at the camp since their birth. I thought it was strange that mum and the driver didn't speak as we made our way along the bumpy red track leading from camp towards town. [...] When we arrived at the station we were surprised to see so many other kids and women waiting on the platform. All the children were happy and running in between the legs of their mothers, playing tips to fill in time. It wouldn't be long before the huge powerful black train pulled into the station. We could see dirty grey smoke from the chimney pouring into the air half a mile away [...] when it was time to take our seat on the train we climbed aboard jubilantly anticipating a joy ride. [...] Mum hadn't taken her seat yet, so we all took turns inspecting the toilet which fascinated us. We knew it wouldn't be long before the train pulled out, so we took our seats again. But we lost Sooty and Robby. When an old white woman in a red hat sat next to me, I changed seats with Barry, as she terrified me. Suddenly I felt scared, and asked: 'Where's Mum?' Barry kept telling us: 'Mum'll be getting on the train in a minute.' I kept asking: 'Where's Sooty, Robby and Mum?' Barry said: 'They must be in the next car.' There were still lots of black women standing on the platform hugging one another. With a sudden jerk, squealing of brakes and a loud puff of the steam engine, the train shunted forward. Fear gripped my little heart. Barry and Widdy had bewildered looks on their faces, glancing at me and then at one another. I stared out of the window as we slowly pulled out of the station. I was very confused. I saw the women standing on the platform watching us and wailing. Then I saw her. There was my mum in her only good blue dress standing next to my aunts and our old grandmother. Just standing there. Standing there with tears rolling down their cheeks too fast to even wipe away. Then Mum waved a white hanky and I pressed my face against the window pane as hard as I could, watching her. Watching until her blue dress faded into a tiny blue daub of colour ${ }^{19}$.

19 Stolen Children..., pp. 98-100. 
Further on, Donna describes the long journey to a completely unknown land - two days by train from her ancestors' Bubu where she knew the spirits and snakes and bush plants. Her brothers were forced to leave in the middle of the journey which was really heartbreaking as the oldest fought to stay because he had promised his Mum to look after his sister. Donna quickly realized there were not many "black fellas" in the new land. She ran out of tears. After two days journey, she met her new parents at the station. The child was simply informed that from now on they would be her new mum and dad. Donna's story proves that the mistreatment and abuse in new places was not the main reason for the trauma of the stolen children. The displacement was. Aboriginal people are deeply culturally rooted in the land of their ancestors that even when surrounded by loving people they cannot adapt.

To maintain objectivity, it is also worth quoting Confidential Evidence 821 from Western Australia which depicts the children's removal by the use of direct physical force (in Donna's case it was by deceit), and therefore can be classified as genocide in accordance with the Convention on the Prevention and Punishment of the Crime of Genocide (1948):

I was at the post office with my Mum and Auntie [and cousin]. They put us in the police ute and said they were taking us to Broome. They put the mums in there as well. But when we'd gone [about ten miles] they stopped, and threw the mothers out of the car. We jumped on our mothers' backs, crying, trying not to be left behind. But the policemen pulled us off and threw us back in the car. They pushed the mothers away and drove off, while our mothers were chasing the car, running and crying after us. We were screaming in the back of that car. When we got to Broome they put me and my cousin in the Broome lock-up. We were only ten years old. We were in the lock-up for two days waiting for the boat to Perth ${ }^{20}$.

Although these two testimonials vary in almost all aspects - from stylistics to the level of violence in the traumatic events they describe - one element clearly comes to the fore: that is the Mother's figure. When analyzing the cathartic texts of Stolen Children, it must be noted that the victims rarely blame the system or the people who directly inflicted physical suffering on them, and most often all regrets and hatred that is expressed in the testimonies is blamed on the mothers. Although the length of this article does not allow citing a representative number of testimonies, it is still evident that this motive is a leading one in the majority of memoirs. The words of two more victims, Lance and Murray, confirm these same feelings towards their mothers.

20 National Report..., p. 6 (Confidential evidence 821, Western Australia: these removals occurred in 1935, shortly after Sister Kate's Orphanage, Perth, was opened to receive 'lighter skinned' children; the girls were placed in Sister Kate's). 
Lance's story (Confidential Evidence 154) starts with the following words: "Lance's mother loves him but he hates her because she allowed him to be taken away from her." He sums up with the words: "If someone tried to remove my kids - over my dead body. I'd pack them up and move them away. Not the shit I've been through - no"21. Some infantilisms of reasoning and a very one-sided perception is striking in this testimony. One can also easily notice that the victims never blame their fathers - their absence was something natural in the Aboriginal culture of that time. The victims seem to fail to understand the power of duress that the oppressors used when they tried to take a child from an Aboriginal mother without using actual physical force 22 .

Murray's tale is the last testimony referred to here. This is a key to the conclusions of this article. This story clearly indicates that the trauma of the Stolen Generation is not connected in the memories and the subconscious of the victims with corporal punishment during life at the missions, experiencing racism or harassment at every stage. Murray was writing a diary because it had been recommended to him by a psychotherapist. As he writes, he was a victim of "litter separation tactics". In 1985, he found his youngest sister Olive. The siblings had been told before she had died of meningitis, but in fact the beautiful girl was adopted by a white family and raised in Brisbane. It will be a longer testimony, but its importance for reflection on the trauma of Stolen Generation presented in the memoirs cannot be overestimated. Murray recalls:

21 The Stolen Children..., pp. 75-78.

22 According to The National Report p. 6: 'Duress' differs from 'compulsion' in that it can be achieved without the actual application of force. However, we usually understand it to involve threats or at least moral pressure. One meaning of 'duress' is 'the infliction of hardship' (Garner 1995 page 300) while another encompasses the threat of such infliction (Mozley and Whiteley 1988 page 153). Definitions commonly refer to illegally applied compulsion, a feature which distinguishes duress from compulsion because compulsion can be either legal or illegal. The last feature of duress is that it does not exclude acceptance by those affected by it. Rather the individual submits to what is demanded. The Inquiry heard evidence of a range of practices which in our view amounted to duress. For example, we were told that a large number of parents relinquished their children to the care of the Lutheran mission, Koonibba, in South Australia to protect them from being removed by the Protector and placed further away. At Koonibba the parents were permitted limited and supervised access. Dr Nick Kowalenko evidence 740, Lutheran Church SA submission 262: I remember another friend of mine in St Ives. She wanted to adopt a little Aboriginal baby. And she was telling me when she got this little one that she went out to the mission and said she wanted a little baby boy. The mission manager said, 'Mrs J has a couple of boys [already], we'll take her third one'. So they adopted that child. If Mrs J would have objected, she said the welfare officer says, 'Well, if you don't give us that child, we'll take the other two'. 
It was as though someone had turned the lights out - a regimented existence replacing our childhood innocence and frolics - the sheer snugness, love, togetherness, safety and comfort of four of us sleeping in one double bed - family! Strange how the bureaucracy adopt the materialistic yardstick when measuring poverty/deprivation/neglect [...] I do remember my mother showing up for visits, supervised visits. We used to get excited. I just wanted her to get us away from there. Then the visits suddenly stopped. I'm told the authorities stopped them because she had a destabilising effect on us. That didn't deter my mother. She used to come to the school ground to visit us over the fence. The authorities found out about those visits. They had to send us to a place where she couldn't get to us. To send us anywhere on mainland Queensland, she would have just followed - so they sent us to the one place where she can't follow: Palm Island Aboriginal Settlement. By our mother visiting us illegally at that school ground she unknowingly sealed our fate. I wasn't to see my mother again for ten nightmare years. I remember when I learnt to write letters, I wrote to my mother furiously pleading with her to come and take us off that island. I wrote to her for years, I got no reply then I realized that she was never coming for us; that she didn't want us. That's when I began to hate her. Now I doubt if any of my letters ever got off that Island or that any letters she wrote me ever stood a chance of me receiving them. [...] As the years of my childhood went by, a son's love for his mother turned to hatred that destroys any feeling of love for anyone. [...] I was the last to leave the Island. After about 18 months drifting on the mainland, my older sister led me back to see my mother, I didn't want to have anything to do with her. So I went more out of curiosity than anything else. When we met we were both strangers. Something was lost, taken, stolen. The gap was too wide to be bridged. I spent a few weeks with her to try to get to know her again but it wasn't to be. I used to catch her looking at me in a sad sort of a way many times. Sometimes I woke up suddenly to see her sitting there watching me with that sad look. When I left this woman I used to call Mum as a little boy, I knew in my heart that I was never to see her again, ever. I was 18 years old and I was dead right. My mother spent the final years of her life with my older sister. Towards the end her mind went. She wasn't stark raving mad, she just needed constant supervision so she wouldn't wander off. My mother died on the first day of January 1977, a tormented and broken woman. She was 57. My mate, Joe, said to me that the worst thing that could ever happen to any woman, black or white, was to have her children taken from her. I can see a lot clearer now. I was too blind to see before. I wept silent bitter tears at my mother's funeral. I wept for the five children. I wept for a mother I never knew. Thirty years on. When I wake awake at night and the dark memories come clouding in on me, I keep seeing a scene in my mind of a woman crying at the end of my bed I can't see her face in the darkness, is it her? My sister seems to think so, she said our mother cried a lot when we were young. Is it a memory trying to break through? [...] Well dear reader and travelling companion. [...] Before we part company to continue our separate journeys through life, I want you to know that I did find something. Perhaps I did not lose it at all, perhaps it lay buried under a lifetime of bad memories. What I found was forgiveness and a love for my mother they took away from $\mathrm{me}^{23}$.

23 The Stolen Children..., pp. 48-51. 
The testimony clearly demonstrates how the analysis of literary texts enhances better understanding of the traumatic experiences of their authors. In Murray's case, his writing had a clearly cathartic function. As Donald Winnicot observes: "The mother is always a traumatizing character"24. This statement gains fundamental significance here.

How to understand this theory when the reader probably has a completely different opinion of Murray's mother? Winnicot is convinced of "the fact that a child's basic trust or idealisation of a nurturing presence carries a great risk of injury, the stronger the idealization, the greater the vulnerability"25. In analyzing literary testimonies this way, one can explore the causes of the victims' existential crisis of the Stolen Generation and come to very surprising conclusions and better understanding of the authors. Broken family bonds, displacement and forced migration to places that are hostile, where ancestors' spirits do not protect them, loss of a language and culture but also, or maybe primarily, the loss of confidence in mothers exhorted a huge impact on the state of the Aboriginal population today. Donna, raised in a pastor's family, has emotional difficulties although she was surrounded by love and prosperity. Did the blue fading point - of her mother's dress, which she still sees on the horizon - determine her fate? Maybe she feels her mother did nothing to stop her. She gave her up without a fight.

In conclusion, I would like to quote Cathy Caruth, the first to develop the theory elaborating on the suggestion that proper reading practice has an ethical value. She "claims that reading practice should come invested with ethical significance as the new mode of reading and of listening that trauma demands can help break the isolation imposed on both individuals and cultures by traumatic experience:" 26 "History, like trauma, is never simply one's own, ... history is precisely the way we are implicated in each other's traumas" 27.

24 G.H. Hartman, Wiedza traumatyczna i badania literackie, [in:] Antologia studiów nad trauma, ed. T. Łysak, Universitas, Kraków 2015, p. 396.

25 Ibidem.

26 S. Craps, Beyond Eurocentrism: Trauma Theory in the Global Age', [in:] The Future of Trauma Theory: Contemporary Literary and Cultural Criticism, ed. G. Buelens, S. Durrant, R. Eaglestone, Abingdon, Routledge 2014, p. 45.

27 C. Caruth, Unclaimed Experience: Trauma, Narrative, and History, The John Hopkins University, Baltimore 1996, p. 24. 


\section{References}

\section{Primary sources}

Report of the National Inquiry into the Separation of Aboriginal and Torres Strait Islander Children from Their Families, Commonwealth of Australia 1997, 524 pp.

The Stolen Children - Their Stories, Ed. Carmel Bird, Random House Australia Pty Ltd, Sydney 1998, 188 pp.

\section{Secondary sources}

Caruth C., Bojarska K.: Teoria traumy jako siła lektury [The theory of trauma as a reader's strength], IBL PAN, "Teksty Drugie" 2010, 124-136 pp.

Caruth C., Trauma and Experience, [in:] Trauma: Explorations in Memory, ed. C. Caruth, The John Hopkins University Press, Baltimore and London 1995, 278 pp.

Caruth C., Unclaimed Experience - Trauma, Narrative, and History, The John Hopkins University, Baltimore 1996, 168 pp.

Craps S., Beyond Eurocentrism: Trauma Theory in the Global Age, [in:] The Future of Trauma Theory: Contemporary Literary and Cultural Criticism, Ed. G. Buelens, S. Durrant, R. Eaglestone, Abingdon, Routledge 2014, 45-61 pp.

Głowiński M., Okopień-Sławińska A., Sławiński J., Zarys teorii literatury [The Outline of Literary Theory], PWN, Warszawa 1991, 547 pp.

Hartman G.H., Wiedza traumatyczna i badania literackie [Traumatic Knowledge and Literary Research], [in:] Antologia studiów nad Traumq [The Anthology of Trauma Studies], ed. T. Łysak, Universitas, Kraków 2015, 377-415 pp.

Kobielska M., Pamięć zbiorowa $w$ centrum nowoczesności. Ujęcie Jeffreya $K$. Olicka [Collective memory in the center of modernity. The approach of Jeffrey K. Olick], IBL PAN, “Teksty Drugie" 2010, No 6, 179-194 pp.

Tozzi V., Przywileje świadectwa. Historia, pamięć i literatura w sporach o konstruowanie nieodległej przeszłości, transl. E. \& J. Zięba, A. Calderón Puerta, "Teksty Drugie" 2010, No 6, 11-26 pp.

White H., The Question of Narrative in Contemporary Historical Theory, "History and Theory", Wesleyan University Press, Vol. 23, No.1 (Feb., 1984), 1-33 pp., https://www.jstor.org/stable/2504969 [accessed: 12.04.2019], DOI: http://dx.doi.org/10.2307/2504969.

Wójcik-Dudek M., W(y)czytać zagładę [To Read-Out the Doom], Uniwersytet Śląski, Katowice 2016, 336 pp. 


\title{
Wysiedlenia i separacja rodzin Aborygenów w świetle wspomnień „skradzionego pokolenia”
}

\begin{abstract}
Streszczenie
Losy rdzennych mieszkańców podczas kolonizacji od zawsze były tematem szeroko dyskutowanym i poddawanym dogłębnej analizie. Niemniej jednak, przymusowa migracja wewnętrzna australijskich Aborygenów oraz sposób, w jaki rząd zrealizował brutalny plan oddzielenia tubylczych dzieci od ich rodzin i ziemi przodków, jest zjawiskiem bezprecedensowym. Trauma przesiedlonych, rozdzielonych z rodzinami nie skończyła się, ale nadal wywiera dramatyczny wpływ na pokolenia rdzennych mieszkańców, ponieważ ich dobrostan jest ściśle powiązany z ziemią ich przodków, z którą interakcja jest dla nich niezbędna i podobna do relacji międzyludzkich. Celem niniejszego artykułu jest przybliżenie problematyki traumy Aborygenów na podstawie analizy ich wspomnień zebranych przez komisję rządową pracującą nad opublikowaniem Raportu Narodowej Komisji Dochodzeniowej w sprawie rozdzielenia aborygeńskich dzieci i ich rodzin - Sprowadźmy ich do domu. Autorka, nawiązując do współczesnych teorii traumy, analizuje materiał mający - niezaprzeczalnie wartość faktograficzną.
\end{abstract}

Słowa kluczowe: Aborygeni, „skradzione pokolenie”, trauma międzypokoleniowa, wysiedlenie, przymusowa migracja wewnętrzna.

\section{Aussiedlung und Familientrennung in den Erinnerungen der betroffenen Aborigines der sogenannten Stolen Generation}

\section{Zusammenfassung}

Das Schicksal der Eingeborenen während der Kolonisation wird schon seit langem thematisiert, diskutiert und eingehend analysiert. Trotzdem ist die erzwungene innere Emigration der Aborigines und die Art und Weise, wie die Regierung Australiens den brutalen Plan der Trennung der Kinder von ihren Familien und der Entwurzelung durchgeführt hat, einmalig in der Geschichte. Das Trauma der Ausgesiedelten dauert an und hat einen dramatischen Einfluss auf die neue Generation, denn ihr Wohlbefinden ist mit dem Land der Vorfahren unzertrennlich verbunden. Die Aborigines befinden sich mit ihrem Land in einer Art Interaktion, die den zwischenmenschlichen Beziehungen ähnelt. Die Autorin setzt sich zum Ziel, den Leser mit dieser Traumatisierungsgeschichte anhand der Erinnerungen der betroffenen Aborigines (aus der sog. „Stolen Generation“) vertraut zu machen. Diese Berichte wurden von dem Nationalen Untersuchungsausschuss gesammelt, der von der Regierung Australiens eingesetzt wurde, um die Fälle der Zwangstrennung zu dokumentieren und den einschlägigen Abschlussbericht „Holen wir sie heim“ zu erarbeiten. Unter Einbeziehung aktueller Trauma-Theorien wird das Material analysiert, das zweifelsohne von hohem faktografischem Wert ist.

Schlüsselwörter: Die Aborigines, Stolen Generation, generationsübergreifendes Trauma, Verdrängung, erzwungene innere (interne) Migration. 